\title{
18. A STUDY OF SEDIMENTATION AT DSDP HOLE 379A, BLACK SEA, BASED ON THE ISOTOPIC COMPOSITION OF STRONTIUM ${ }^{1}$
}

\author{
C.D. Nardone and G. Faure, Department of Geology and Mineralogy, \\ The Ohio State University, Columbus, Ohio
}

\begin{abstract}
The ${ }^{87} \mathrm{Sr} /{ }^{86} \mathrm{Sr}$ ratios and $\mathrm{Sr}$ concentrations of detrital noncarbonate fractions of sediment deposited in the central basin of the Black Sea are controlled to a first approximation by varying proportions of sialic and mafic components. The sialic component consists of weathering products of igneous, metamorphic, and sedimentary rocks of Precambrian to Tertiary age in the northern watershed. The mafic component originates from ophiolite complexes and associated volcanic rocks and volcanogenic sediment of Mesozoic to Cenozoic age in Turkey and Bulgaria. Quantitative interpretations of the data yield mixing equations from which the $\mathrm{Sr}$ concentrations of the sialic and mafic components are estimated using reasonable assumed values of their ${ }^{87} \mathrm{Sr} /{ }^{86} \mathrm{Sr}$ ratios. For the mafic component we assumed ${ }^{87} \mathrm{Sr} /{ }^{86} \mathrm{Sr}=0.705 \pm 0.001$ and obtained a $\mathrm{Sr}$ content of $215 \pm 38 \mathrm{ppm}$. The concentration of $\mathrm{Sr}$ in the sialic component is $50.4 \pm 3.3 \mathrm{ppm}$, assuming that its ${ }^{87} \mathrm{Sr} /{ }^{86} \mathrm{Sr}$ ratio is $0.735 \pm 0.005$. The data suggest that slight variations of these values occurred for limited intervals of time. The concentrations of the sialic component, calculated from the two-component mixing model, vary systematically as a function of depth in the hole and indicate a strong climatic influence on the input of sialic detritus from the northern watershed, as follows: Würm glacial: $59 \%$; Würm/Riss interglacial: $51 \%$; Riss glacial: $67 \%$; Mindel/Riss interglacial (?): $37 \%$; Mindel glacial: $84 \%$.

The ${ }^{87} \mathrm{Sr} /{ }^{80} \mathrm{Sr}$ ratios of the calcium carbonate fractions in Cores 1 through 22 range from 0.7070 to 0.7084 and are less than the value of this ratio in modern seawater $(0.709)$. The low values are attributable to the presence of reworked older coccoliths of Cretaceous and Eocene to Oligocene age which have lower ${ }^{87} \mathrm{Sr} /{ }^{86} \mathrm{Sr}$ ratios than indigenous species of Quaternary age. The average ${ }^{87} \mathrm{Sr} /{ }^{86} \mathrm{Sr}$ ratio of carbonates deposited during the Wurm/Riss interglacial is greater than that of the Würm glacial period due to the predominance of the indigenous species Emiliania huxleyi during periods of increased salinity (interglacials) in the Black Sea. The isotopic composition of $\mathrm{Sr}$ in the carbonate phases therefore has some value as an indicator of salinity in the Black Sea.
\end{abstract}

\section{INTRODUCTION}

This study is based on the hypothesis that the detrital non-carbonate fraction of sediment deposited in the central basin of the Black Sea consists of two components having different ${ }^{87} \mathrm{Sr} /{ }^{86} \mathrm{Sr}$ ratios and $\mathrm{Sr}$ concentrations. The sediment derived from the northern watershed originated by weathering of igneous, metamorphic, and sedimentary rocks of generally sialic composition and widely varying age from Precambrian to Tertiary. This component consists primarily of feldspar, quartz, garnet, illite, kaolinite (identified by Müller and Stoffers, 1974), and various oxides which collectively have a low $\mathrm{Sr}$ concentration

'Laboratory of Isotope Geology and Geochemistry Contribution No. 41. (less than $100 \mathrm{ppm}$ ), but are enriched in ${ }^{87} \mathrm{Sr}$ due to decay of ${ }^{87} \mathrm{Rb}$ in the rocks from which they were derived. The second component originates primarily in Turkey and to a lesser extent from Bulgaria. It is characterized by the presence of mafic minerals (plagioclase, pyroxenes, amphiboles, and montmorillonite) removed from ophiolite complexes and associated volcanic rocks and volcanogenic sediment of late Mesozoic to Cenozoic age (Müller and Stoffers, 1974; Brinkman, 1974; Vuchev, 1974; Kamen-Kaye, 1971). This component has a high $\mathrm{Sr}$ concentration (greater than $200 \mathrm{ppm}$ ) and low ${ }^{87} \mathrm{Sr} /{ }^{86} \mathrm{Sr}$ ratio consistent with the mafic composition and young geologic age of the source rocks (Faure and Powell, 1972). The hypothesis suggests that the $\mathrm{Sr}$ concentrations and ${ }^{87} \mathrm{Sr} /{ }^{86} \mathrm{Sr}$ ratios of detrital non-carbonate sediment in the central basin of the Black Sea should be controlled to a first approximation by the relative proportions of sialic 
(northern) and mafic (southern) silicate detritus present in a given sample.

The hypothetical sialic component was transported to the Black Sea by large meltwater streams and their modern successors that drain its northern watershed, including the Danube, Dnepr, Don, Kuban, Dnester, Bug, and others. The mafic component is contributed by several Turkish rivers such as the Kizil Irmak, Yesil Irmak, Coruh, and many other lesser streams. The input of sediment from the northern watershed during the Pleistocene epoch probably varied between wide limits in response to the advances and retreats of the continental ice sheet. The amount of sediment transported by the rivers in Turkey (and Bulgaria) during the same period probably remained fairly constant because this region remained free of ice. Consequently, we propose that the ratio of sialic (northern) to mafic (southern) non-carbonate detritus deposited at a given site in the Black Sea during the Pleistocene epoch varied in response to the waxing and waning of the ice sheets. The abundance of the sialic (northern) component increased during periods of glaciation and decreased during interglacials after most of the ice in northern Europe had melted. These climatically controlled changes in the mineralogical composition of the sediment should therefore be reflected by corresponding variations of its $\mathrm{Sr}$ concentration and ${ }^{87} \mathrm{Sr} /{ }^{86} \mathrm{Sr}$ ratio: high $\mathrm{Sr}$ concentrations and low ${ }^{87} \mathrm{Sr} /{ }^{86} \mathrm{Sr}$ ratios during interglacials and low $\mathrm{Sr}$ concentrations and high ${ }^{87} \mathrm{Sr} /{ }^{86} \mathrm{Sr}$ during glacial periods.

This hypothesis is supported by ${ }^{87} \mathrm{Sr} /{ }^{86} \mathrm{Sr}$ ratios and $\mathrm{Sr}$ concentrations of alumino-silicate detritus from piston core $1474\left(42^{\circ} 23^{\prime} \mathrm{N}\right.$ lat; $37^{\circ} 37^{\prime} \mathrm{E}$ long) published by Cooper et al. (1974). Their data show that the ${ }^{87} \mathrm{Sr} /{ }^{86} \mathrm{Sr}$ ratios of the non-carbonate fraction of this core ranged from 0.7077 to 0.7101 (average ${ }^{87} \mathrm{Sr} /{ }^{86} \mathrm{Sr}=$ 0.7088 ) in the upper $310 \mathrm{~cm}$ and then increased to 0.7120 at $400 \mathrm{~cm}$ and 0.7150 at $600 \mathrm{~cm}$. The increase of the ${ }^{87} \mathrm{Sr} /{ }^{86} \mathrm{Sr}$ ratio is accompanied by a decrease of the Sr concentration from $173 \mathrm{ppm}$ above $310 \mathrm{~cm}$, to 122 $\mathrm{ppm}$ at $400 \mathrm{~cm}$ and to $99.2 \mathrm{ppm}$ at $600 \mathrm{~cm}$. Using carbon-14 dates of Ross and Degens (1974), one can infer that the change occurred around 13,800 years B.P. toward the end of the Würm glaciation. Cooper et al. (1974) also analyzed sediment from core tops and observed that the ${ }^{87} \mathrm{Sr} /{ }^{86} \mathrm{Sr}$ ratios of the alumino-silicate fractions ranged from 0.7099 and 0.7130 near the Turkish coast up to 0.7179 along the eastern, northern, and western parts of the basin. These results are therefore consistent with the hypothesis outlined above.

The calcium carbonate fraction of sediment of late Pleistocene to Holocene age in the Black Sea is composed predominantly of coccoliths. Bukry (1974) observed that sediment of Holocene age (Units 1 and 2) contains the indigenous species Braarudosphaera bigelowi and Emiliania huxleyi, whereas Unit 3 is characterized by the exclusive presence of reworked coccoliths of Late Cretaceous to Eocene age. According to measurements by Cox and Faure (1974), the ${ }^{87} \mathrm{Sr} /{ }^{86} \mathrm{Sr}$ ratios of the carbonate fractions of Holocene sediment (Unit 1) are identical to that of $\mathrm{Sr}$ in water of the Black Sea which has an ${ }^{87} \mathrm{Sr} /{ }^{86} \mathrm{Sr}$ ratio of 0.7093 \pm 0.0007 . However, the carbonates of Unit 3 , deposited during the Würm glaciation, have a significantly lower ${ }^{87} \mathrm{Sr} /{ }^{86} \mathrm{Sr}$ ratio of $0.7073 \pm 0.0003$. This value is compatible with the isotopic composition of $\mathrm{Sr}$ in the oceans during Late Cretaceous to Eocene time (Peterman et al., 1970) and is consistent with the identification of the coccoliths. Therefore, Cox and Faure (1974) concluded that the ${ }^{87} \mathrm{Sr} /{ }^{86} \mathrm{Sr}$ ratios of the carbonate phases are indirect indicators of the salinity in the Black Sea. During glacial periods, when the water was brackish to fresh, redeposited coccoliths of Late Cretaceous to Eocene age, having ${ }^{87} \mathrm{Sr} /{ }^{86} \mathrm{Sr}$ ratios between 0.707 and 0.708 , dominated the carbonate content of the sediment. During interglacials, the ${ }^{87} \mathrm{Sr} /{ }^{86} \mathrm{Sr}$ ratios of the carbonates increased to 0.709 as indigenous coccolith species re-established themselves in more saline water resulting from the influx of water from the Mediterranean Sea.

One of the objectives of the present study is concerned with interpretations of ${ }^{87} \mathrm{Sr} /{ }^{86} \mathrm{Sr}$ ratios and $\mathrm{Sr}$ concentrations of the detrital non-carbonate fractions of sediment from Hole 379A in terms of twocomponent mixing models in order to evaluate the influence of climatic variations on sediment provenance. A second objective is to confirm the hypothesis of Cox and Faure (1974) by analysis of the carbonate fractions of sediment from Hole 379A. The results of these two investigations should be complementary and should be compatible with the conclusions derived by other methods described elsewhere in this volume. In addition, we hope that the results of this study will demonstrate the usefulness of the isotopic composition of $\mathrm{Sr}$ in the interpretation of sedimentary rocks of marine or nonmarine origin.

\section{ANALYTICAL PROCEDURES}

The sediment samples ( 5 to $10 \mathrm{~g}$ ) were dispersed in $250 \mathrm{ml}$ of double distilled and demineralized water, dried, weighed, and then treated with $250 \mathrm{ml}$ of purified $0.1 N \mathrm{HCl}$ in order to dissolve the carbonate fraction. The supernate was decanted and stored for later isotopic analysis of $\mathrm{Sr}$. Any remaining calcium carbonate and most of the iron sulfides were subsequently removed by additional leaching with purified $2 N \mathrm{HCl}$. The carbonate (plus iron sulfide) contents of the samples were calculated from the observed weight loss and were expressed as weight percent relative to the washed and dried sediment.

Concentrations of $\mathrm{Sr}$ of detrital non-carbonate fractions were measured in duplicate by means of X-ray fluorescence using a Mo-target X-ray tube and a $\mathrm{LiF}$ (220) analyzer crystal (Diano Corp., Model XRD-6). A calibration curve was established using the rock standards of the U.S. Geological Survey (G-2, GSP-1, BCR-1, AGV-1, W-1) described by Flanagan (1973). A correction for mass absorption was made by means of the MoK-alpha Compton-scattered peak (Reynolds, 1963). The standard deviation of the Sr determinations is $\pm 1.7 \mathrm{ppm}$, based on duplicate analyses of 66 samples. A suite of 10 samples from Cores 36 to 68 was analyzed, both before and after removal of the acid-soluble fraction, which enabled us to estimate the $\mathrm{Sr}$ contents of their carbonate fractions.

Aliquots of about $0.5 \mathrm{~g}$ of acid-leached sediment were dissolved in a mixture of $\mathrm{HF}+\mathrm{H}_{2} \mathrm{SO}_{4}$ and $\mathrm{Sr}$ was 
extracted from the resulting solutions by cation exchange chromatography. The isotopic composition of $\mathrm{Sr}$ was measured on a solid-source mass spectrometer (Nuclide Corp., Model 6-60-S). The measured ${ }^{87} \mathrm{Sr} /{ }^{86} \mathrm{Sr}$ ratios were corrected for isotope fractionation to ${ }^{86} \mathrm{Sr} /{ }^{88} \mathrm{Sr}=0.1194$. Four samples were analyzed in duplicate from which we calculate a standard deviation of \pm 0.00036 for the fractionation-corrected ${ }^{87} \mathrm{Sr} /{ }^{86} \mathrm{Sr}$ ratios. The Eimer and $\mathrm{Amend} \mathrm{SrCO}_{3}$ standard was analyzed six times in the course of this study and gave an average ${ }^{87} \mathrm{Sr} /{ }^{86} \mathrm{Sr}$ ratio of $0.70806 \pm 0.0002(1 \sigma)$. This value is in excellent agreement with results obtained by other investigators.

\section{NON-CARBONATE FRACTIONS}

The sediment from Hole 379A has been subdivided into nine units on the basis of megascopic compositional criteria. Detailed descriptions of each unit are given in the Site Report for $379 \mathrm{~A}$ and will not be repeated here. Table 1 contains a brief summary of the lithologic character of each unit and indicates their tentative correlations with the glacial chronology of northern Europe.

The interpretation of the ${ }^{87} \mathrm{Sr} /{ }^{86} \mathrm{Sr}$ ratios and $\mathrm{Sr}$ concentrations of the detrital non-carbonate fractions (Table 2) is based on the hypothesis presented earlier that the sediment contains two components derived from the northern and southern watersheds of the Black Sea. The Sr concentration $\left(\mathrm{Sr}_{m}\right)$ of a twocomponent mixture is given by:

$$
\mathrm{Sr}_{m}=\mathrm{Sr}_{s} f+\operatorname{Sr}_{v}(1-f)
$$

where $\mathrm{Sr}_{s}$ and $\mathrm{Sr}_{v}$ are the concentrations of this element in the sialic (northern) and mafic (southern) components, respectively, and where $f$ is the fraction of the sialic component in the mixture by weight. The ${ }^{87} \mathrm{Sr} /{ }^{86} \mathrm{Sr}$ ratio of such mixtures is:

$$
\frac{{ }^{87} \mathrm{Sr}}{{ }^{86} \mathrm{Sr}}=\frac{a}{\mathrm{Sr}_{m}}+b
$$

where $a$ and $b$ are constants whose values are determined by the $\mathrm{Sr}$ concentrations and ${ }^{87} \mathrm{Sr} /{ }^{86} \mathrm{Sr}$ ratios of the end members (Boger and Faure, 1974, 1976; Shaffer and Faure, 1976). Equation 2 is the mixing equation which is a straight line in coordinates of ${ }^{87} \mathrm{Sr} /{ }^{86} \mathrm{Sr}$ and $1 / \mathrm{Sr}$ and is a hyperbola when ${ }^{87} \mathrm{Sr} /{ }^{86} \mathrm{Sr}$ ratios are plotted versus the $\mathrm{Sr}$ concentrations.

TABLE 1

Lithologic Units and Tentative Glacial Chronology of Sediment From DSDP Hole 379A, Black Sea

\begin{tabular}{llccl}
\hline Unit & \multicolumn{1}{c}{ Lithology } & $\begin{array}{c}\text { Thickness } \\
(\mathrm{m})\end{array}$ & Cores & \multicolumn{1}{c}{ Tentative Age } \\
\hline 1 & Nanno ooze & 0.30 & $1 ?$ & Holocene \\
2 & Sapropel & 0.40 & $1 ?$ & Holocene \\
3 & Terrigenous mud & 65 & $1-7$ & Würm G. \\
4 & Diatomaceous nanno mud & 35 & $8-11$ & Riss/Würm 1.G. \\
5 & Sapropel & 0.30 & 11 & Riss/Würm I.G. \\
6 & Terrigenous mud & 130 & $12-24$ & Riss G. \\
7 & Nanno diatomaceous marl & 45 & $25-29$ & Mindel/Riss I.G. \\
8 & Terrigenous mud & 180 & $30-49$ & Mindel G. \\
9 & Calcite-rich mud & 170 & $50-68$ & $\sim 700,000 \mathrm{yr}$ \\
\hline
\end{tabular}

Note: $\mathrm{G}=$ glacial. I.G. $=$ interglacial. The tentative chronology is that of Stoffers et al., this volume.
TABLE 2

Analytical Results for Non-Carbonate Fractions of

\begin{tabular}{|c|c|c|c|c|c|}
\hline & & & & Non- $\mathrm{Ca}$ & bonate \\
\hline Sample & Depth & & Carbonate & & ${ }^{87} \mathrm{Sr}$ \\
\hline (Interval in $\mathrm{cm}$ ) & (m) & Unit & (\%) & Sr ppm & ${ }^{86} \mathrm{Sr}$ \\
\hline $1-1,70$ & 0.70 & $3 ?$ & 24.2 & 121.0 & 0.7117 \\
\hline $1-4,20$ & 4.70 & 3 & 25.2 & 105.8 & 0.7118 \\
\hline $4-3,10$ & 30.10 & 3 & 17.1 & 90.8 & 0.7142 \\
\hline $4-4,50$ & 32.00 & 3 & 23.5 & 94.0 & 0.7138 \\
\hline $4-5,66$ & 33.66 & 3 & 25.6 & 126.2 & 0.7115 \\
\hline $6-1,42$ & 45.42 & 3 & 21.4 & 130.8 & 0.7107 \\
\hline $6-2,42$ & 46.92 & 3 & 19.4 & 126.4 & 0.7135 \\
\hline $6-4,4$ & 49.54 & 3 & 20.6 & 136.4 & 0.7108 \\
\hline $6-5,32$ & 51.32 & 3 & 15.9 & 250.6 & 0.7077 \\
\hline $6-5,126$ & 52.26 & 3 & 20.0 & 147.2 & 0.7100 \\
\hline $6-6,38$ & 52.88 & 3 & 17.2 & 109.9 & 0.7153 \\
\hline $7-2,1$ & 55.51 & 3 & 23.9 & 110.2 & 0.7134 \\
\hline $7-4,16$ & 58.66 & 3 & 21.8 & 97.8 & - \\
\hline $7-5,126$ & 61.26 & 3 & 19.1 & 93.4 & 0.7152 \\
\hline $8-1,14$ & 63.14 & 4 & 16.6 & 116.8 & - \\
\hline $8-5,26$ & 69.26 & 4 & 19.6 & 110.2 & - \\
\hline $9-2,20$ & 73.70 & 4 & 22.3 & 100.9 & - \\
\hline $9-3,62$ & 75.62 & 4 & 15.0 & 166.4 & - \\
\hline $9-4,3$ & 76.53 & 4 & 15.2 & 150.2 & - \\
\hline $9-5,136$ & 79.36 & 4 & 20.7 & 126.1 & - \\
\hline $10-1,110$ & 82.10 & 4 & 20.3 & 168.8 & - \\
\hline $10-3,15$ & 84.15 & 4 & 17.1 & 178.9 & - \\
\hline $10-4,70$ & 86.20 & 4 & 15.3 & 110.9 & 0.7169 \\
\hline $10-5,23$ & 87.23 & 4 & 17.1 & 104.8 & - \\
\hline $10-6,45$ & 89.95 & 4 & 19.4 & 180.2 & - \\
\hline $11-1,110$ & 91.10 & 4 & 27.8 & 127.6 & - \\
\hline $11-2,71$ & 92.21 & 4 & 16.2 & 218.8 & 0.7093 \\
\hline $11-3,30$ & 93.30 & 4 & 13.1 & 138.4 & 0.7145 \\
\hline $11-4,50$ & 95.00 & 4 & 18.8 & 118.8 & 0.7141 \\
\hline $12-1,53$ & 99.53 & 6 & 18.2 & 114.6 & 0.7179 \\
\hline $12-2,24$ & 100.74 & 6 & 17.6 & 101.0 & 0.7239 \\
\hline $12-3,140$ & 103.40 & 6 & 26.4 & 115.7 & - \\
\hline $13-1,25$ & 108.25 & 6 & 23.9 & 125.4 & 0.7102 \\
\hline $13-3,30$ & 111.30 & 6 & 20.5 & 115.6 & 0.7116 \\
\hline $13-4,24$ & 112.74 & 6 & 21.5 & 130.9 & 0.7108 \\
\hline $13-5,21$ & 114.21 & 6 & 18.1 & 105.2 & 0.7154 \\
\hline $13-6,5$ & 115.55 & 6 & 23.8 & 122.0 & 0.7106 \\
\hline $14-1,20$ & 117.20 & 6 & 20.8 & 105.7 & 0.7149 \\
\hline $14-4,16$ & 121.66 & 6 & 20.3 & 114.4 & 0.7135 \\
\hline $14-6,30$ & 124.80 & 6 & 23.9 & 105.2 & - \\
\hline $15-2,14$ & 127.64 & 6 & 15.5 & 213.6 & 0.7079 \\
\hline $15-4,13$ & 130.63 & 6 & 19.8 & 115.6 & - \\
\hline $15-5,7$ & 132.07 & 6 & 19.9 & 111.1 & 0.7145 \\
\hline $16-1,40$ & 135.40 & 6 & 13.6 & 87.6 & 0.7176 \\
\hline $16-2,15$ & 136.65 & 6 & 12.4 & 76.0 & 0.7136 \\
\hline $16-3,32$ & 138.32 & 6 & 13.6 & 67.8 & - \\
\hline $16-4,56$ & 140.06 & 6 & 13.0 & 80.4 & 0.7199 \\
\hline $18-2,48$ & 154.98 & 6 & 20.4 & 95.2 & - \\
\hline $19-1,130$ & 163.30 & 6 & 20.0 & 156.7 & 0.7080 \\
\hline $19-1,140$ & 163.40 & 6 & 11.7 & 229.2 & 0.7073 \\
\hline $19-2,17$ & 163.67 & 6 & 18.5 & 95.3 & 0.7125 \\
\hline $19-5,101$ & 169.01 & 6 & 24.7 & 106.5 & - \\
\hline $20-3,84$ & 174.84 & 6 & 26.0 & 100.9 & 0.7110 \\
\hline $21-2,27$ & 181.77 & 6 & 25.7 & 113.6 & - \\
\hline $21-6,13$ & 187.63 & 6 & 24.9 & 99.1 & 0.7115 \\
\hline $22-6,11$ & 196.61 & 6 & 26.3 & 103.9 & 0.7103 \\
\hline $36-4,73$ & 320.23 & 8 & 23.6 & 87.7 & - \\
\hline $38-4,76$ & 338.26 & 8 & 14.5 & 71.0 & 0.7306 \\
\hline $38-6,15$ & 340.65 & 8 & 13.9 & 64.2 & - \\
\hline $39-5,25$ & 348.25 & 8 & 11.7 & 82.5 & - \\
\hline $43-5,92$ & 384.92 & 8 & 23.3 & 68.4 & - \\
\hline $45-4,111$ & 401.61 & 8 & 25.5 & 199.4 & - \\
\hline $51-2,26$ & 451.76 & 9 & 32.9 & 104.9 & - \\
\hline $54-2,17$ & 478.67 & 9 & 33.4 & 75.0 & - \\
\hline $58-4,89$ & 518.39 & 9 & 42.6 & 99.2 & - \\
\hline $60-4,64$ & 536.14 & 9 & 37.4 & - & - \\
\hline $68-5,100$ & 610.00 & 9 & 32.8 & 117.2 & - \\
\hline
\end{tabular}
Sediment From DSDP Hole 379A, Black Sea 
These relationships tell us that the mixing hypothesis can be tested by plotting the ${ }^{87} \mathrm{Sr} /{ }^{86} \mathrm{Sr}$ ratios of detrital non-carbonate fractions versus the reciprocal of their $\mathrm{Sr}$ concentrations. The validity of the hypothesis is indicated by the goodness of fit of the data points to a straight line which can be fitted by least-squares regression. If the fit is satisfactory, the equation can then be used to estimate $\mathrm{Sr}_{s}$ and $\mathrm{Sr}_{v}$ by substituting reasonable assumed values of the ${ }^{87} \mathrm{Sr} /{ }^{86} \mathrm{Sr}$ ratios. The results can be used in Equation 1 to calculate the concentrations of sialic detritus $(f)$ of any given sample in the suite from its observed $\mathrm{Sr}$ concentration. The effect of changing climatic conditions of sedimentation in the Black Sea should then be reflected by systematic variations in the concentration of sialic detritus derived from the northern watershed.

The analytical results compiled in Table 2 indicate that the calcium carbonate (plus iron sulfide) contents of the samples of Units 1 through 8 are fairly constant (range $11.7 \%$ to $27.8 \%$ ) and average $19.2 \%$. Unit 9 is a calcitic mud with a higher carbonate content of $35.8 \%$. The $\mathrm{Sr}$ concentrations range from 64.2 to $250.6 \mathrm{ppm}$ and average $120.2 \mathrm{ppm}$. Five samples from Units 3, 4, 6 , and $8(6-5,32 \mathrm{~cm}, 11-2,71 \mathrm{~cm}, 15-2,14 \mathrm{~cm}, 19-1,140$ $\mathrm{cm}, 45-4,111 \mathrm{~cm}$ ) have anomalously high $\mathrm{Sr}$ concentrations of $200 \mathrm{ppm}$ or more. These samples consist of sand-sized particles and represent turbiditic sands with graded bedding that are intercalated with the terrigenous mud. Their ${ }^{87} \mathrm{Sr} /{ }^{86} \mathrm{Sr}$ ratios are lower than those of all other samples we have analyzed $(0.7073$ to 0.7093 ) and average 0.7080 . The high $\mathrm{Sr}$ content and low ${ }^{87} \mathrm{Sr} /{ }^{86} \mathrm{Sr}$ ratios suggest that the turbidite layers are enriched in mafic minerals and presumably originated from the continental shelf and slope of the Turkish coast. The sandy layers were deposited by turbidity currents and therefore do not satisfy our sedimentation model.

All of the samples for which both ${ }^{87} \mathrm{Sr} /{ }^{86} \mathrm{Sr}$ ratios and $\mathrm{Sr}$ concentrations are available have been plotted in Figure IA, using different symbols to identify the lithologic units. Most of the samples are from Units 3 and 6 representing sediment of Würm and Riss age, respectively. The Würm/Riss interglacial interval (Unit 4 ) is represented by only four samples, one of which is a turbidite. Additional analyses for Units 4, 8, and 9 are in progress and will be reported elsewhere. One sample from Unit 8 (38-4-76, Mindel glaciation) has a $\mathrm{Sr}$ content of $71.0 \mathrm{ppm}$ and an ${ }^{87} \mathrm{Sr} /{ }^{86} \mathrm{Sr}$ ratio of 0.7306 . This is the highest isotopic ratio of the samples we have analyzed and suggests a very high content of sialic detritus in Unit 8.

When the samples from Units 3 and 6 are examined separately (Figures IB and D), the positive correlation of the ${ }^{87} \mathrm{Sr} /{ }^{86} \mathrm{Sr}$ ratios with reciprocals of the $\mathrm{Sr}$ concentrations is quite apparent. However, certain samples deviate markedly from the linear patterns. These anomalous samples include the turbidites as well as small sets of samples which are stratigraphically related and appear to form distinctive linear arrays. Nevertheless, eight samples from Unit 3 fit a mixing line whose equation is:

$$
\frac{{ }^{87} \mathrm{Sr}}{{ }^{86} \mathrm{Sr}}=0.6966+\frac{1.930}{\mathrm{Sr}}
$$

Eleven of the samples of Unit 6 fit a very similar line represented by:

$$
\frac{{ }^{87} \mathrm{Sr}}{{ }^{86} \mathrm{Sr}}=0.6951+\frac{2.020}{\mathrm{Sr}}
$$

The similarity of the mixing equations for these two units indicates that the ${ }^{87} \mathrm{Sr} /{ }^{86} \mathrm{Sr}$ ratios and $\mathrm{Sr}$ concentrations of the sialic and mafic components of sediment that entered the Black Sea during the Würm and $\mathrm{R}$ iss glaciations remained essentially the same. For this reason we combined Equations 3 and 4 to obtain a single mixing equation that is satisfied by most, but not all, of the samples we have analyzed:

$$
\frac{{ }^{87} \mathrm{Sr}}{{ }^{86} \mathrm{Sr}}=0.6958+\frac{1.975}{\mathrm{Sr}}
$$

This equation was plotted in Figure $1 \mathrm{C}$ in order to determine to what extent the samples of Unit 4 (Würm/Riss interglacial) fit the general mixing equation. We conclude only that the fit is poor, but that it permits the assumption that the sediment in this unit consists of mixtures of two components similar to those of Units 3 and 6.

Samples 1-4, $20 \mathrm{~cm}, 4-3,10 \mathrm{~cm}$, and 4-4, $50 \mathrm{~cm}$, form a subset (labeled 3-1) within the upper 32 meters of Unit 3 to which we have also assigned $7-5,126 \mathrm{~cm}$. These four samples lie on a mixing line whose equation is:

$$
\frac{{ }^{87} \mathrm{Sr}}{{ }^{86} \mathrm{Sr}}=0.695+\frac{1.826}{\mathrm{Sr}}
$$

In addition, the samples from Cores 19, 20, 21, and 22 in Unit 6 can be distinguished in Figure ID by a separate line (subset 6-1):

$$
\frac{{ }^{87} \mathrm{Sr}}{{ }^{86} \mathrm{Sr}}=0.686+\frac{2.540}{\mathrm{Sr}}
$$

A second subset (6-2) is suggested by the samples from Core $12(12-1,53 \mathrm{~cm}, 12-2,24 \mathrm{~cm})$ which form a distinctly different line whose equation is:

$$
\frac{{ }^{87} \mathrm{Sr}}{{ }^{86} \mathrm{Sr}}=0.673+\frac{5.110}{\mathrm{Sr}}
$$

These three subsets deviate from the main group perhaps because the mineral compositions of either the sialic or the mafic component, or both, changed during certain intervals of time. Such changes in the mineral composition may have been caused by subtle changes in the processes that transported terrigenous sediment to Hole 379A. In any case, the data indicate that the $\mathrm{Sr}$ concentrations and ${ }^{87} \mathrm{Sr} /{ }^{86} \mathrm{Sr}$ ratios of the sediment components assumed different values for relatively 

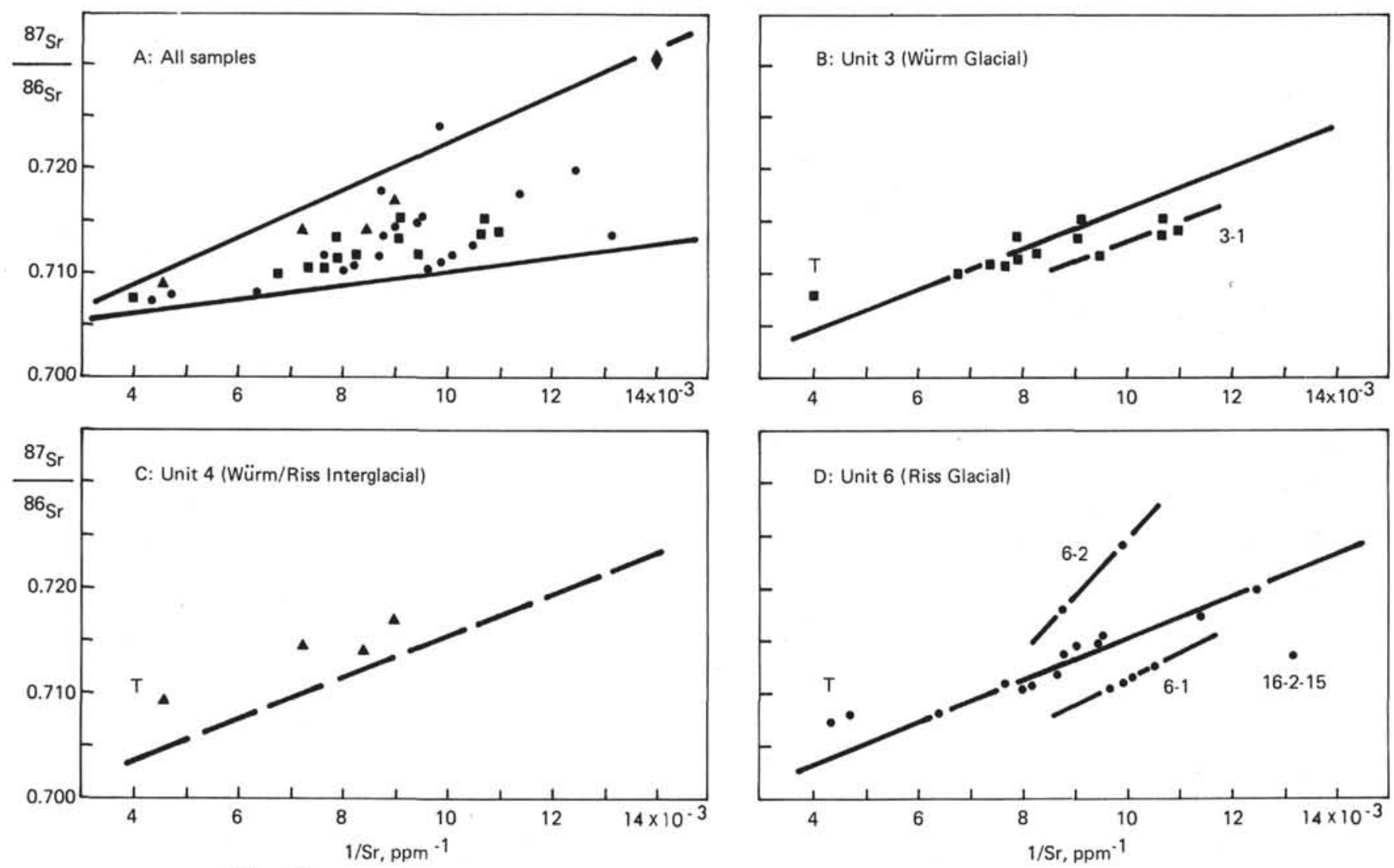

Figure 1. Plots of ${ }^{87} \mathrm{Sr} /{ }^{86} \mathrm{Sr}$ ratios of detrital non-carbonate fractions of DSDP Hole $379 \mathrm{~A}$ versus reciprocals of their Sr concentrations. The lithologic units are defined in Table 1. Colinear arrays of data points 3-1, 6-1, and 6-2 are subsets of these respective units which presumably reflect changes in the compositions of the sialic (northern) and mafic (southern) components. Turbidite sands are identified by the letter T.

short intervals of time. Finally we note that another sample from Unit $6(16-2,15 \mathrm{~cm})$ deviates significantly from the "main sequence." We attribute the anomalous composition of this sample to the short-term heterogeneity of the sialic component, but are unable to determine whether it belongs to a third subset within Unit 6.

In general, the foregoing examination of the data indicates that most of the samples in Units 3 and 6 fit a single mixing equation (5) and therefore can be treated as mixtures of two components. The $\mathrm{Sr}$ concentrations of the sialic and mafic components can be estimated by substituting their assumed ${ }^{87} \mathrm{Sr} /{ }^{86} \mathrm{Sr}$ ratios into Equation 5. No measurements of the isotopic composition of $\mathrm{Sr}$ in the Mesozoic volcanics of Turkey have been reported. However, the ${ }^{87} \mathrm{Sr} /{ }^{86} \mathrm{Sr}$ ratio of the mafic component should be less than 0.7073 (the lowest value in turbidite Sample 19-1, $140 \mathrm{~cm}$ ) and greater than 0.7030 , which is representative of young oceanic tholeiites (Peterman and Hedge, 1971). The only data that may be relevant here are the ${ }^{87} \mathrm{Sr} /{ }^{86} \mathrm{Sr}$ ratios of mafic rocks from the Troodos Massif on Cyprus reported by Peterman et al. (1971). They obtained ratios ranging from 0.7040 to 0.7057 with an average of 0.7049 for 10 rock samples. On this basis we select a value of $0.705 \pm 0.001$ for the ${ }^{87} \mathrm{Sr} /{ }^{86} \mathrm{Sr}$ ratio of the mafic component and estimate its $\mathrm{Sr}$ content from Equation 5 as $215 \pm 28 \mathrm{ppm}$.
The ${ }^{87} \mathrm{Sr} /{ }^{86} \mathrm{Sr}$ ratio of the sialic component is very probably greater than 0.730 because Sample $38-4,76 \mathrm{~cm}$ has a ratio of 0.7306 . On the other hand, it seems very unlikely to us that its ${ }^{87} \mathrm{Sr} /{ }^{86} \mathrm{Sr}$ ratio is higher than 0.740 because this value implies an average age of about 880 million years for the rocks in the northern drainage basin. This date is based on a $\mathrm{Rb} / \mathrm{Sr}$ ratio of 1.02 reported by Cooper et al. (1974) for acid-leached core-top sediment from the Black Sea. The rocks exposed in the present watershed north of the Black Sea are predominantly of Phanerozoic age (Müller and Stoffers, 1974). However, it is probable that detritus of Precambrian age may have reached the Black Sea during glacial periods. Nevertheless, we regard 0.740 as an upper limit and assume a value of $0.735 \pm 0.005$ for the ${ }^{87} \mathrm{Sr} /{ }^{80} \mathrm{Sr}$ ratio of the sialic component. This value leads to an estimated $\mathrm{Sr}$ content of this component equal to $50.4 \pm 3.3 \mathrm{ppm}$. The low $\mathrm{Sr}$ content indicates that the sialic component delivered to Hole $379 \mathrm{~A}$ consists primarily of clay minerals and other weathering products of sialic rocks. The higher $\mathrm{Sr}$ content of the mafic component may be due to the presence of plagioclase and unweathered particles of mafic volcanic rock. The $\mathrm{Sr}$ concentrations of the sialic and mafic components implied by the mixing equations (3 to 8) are listed in Table 3. The estimated $\mathrm{Sr}$ concentrations of the sialic component range from 45.7 to $82.4 \mathrm{ppm}$, those of the mafic component from 134 to 
TABLE 3

Strontium Concentrations of the Sialic and Mafic Components Derived From the Mixing Equations ( 3 to 8 ) for $\left.f^{87} \mathrm{Sr} /{ }^{86} \mathrm{Sr}\right)_{v}=0.705 \pm 0.001$ $\left({ }^{87} \mathrm{Sr} /{ }^{86} \mathrm{Sr}\right)_{S}=0.735 \pm 0.005$

\begin{tabular}{|c|c|c|c|c|}
\hline \multirow{2}{*}{$\begin{array}{l}\text { Unit or } \\
\text { Subset }\end{array}$} & \multirow[b]{2}{*}{ Cores } & \multirow[b]{2}{*}{ Equation } & \multicolumn{2}{|c|}{ Sr Concentration (ppm) } \\
\hline & & & Sialic $\left(\mathrm{Sr}_{s}\right)$ & Mafic $\left(\mathrm{Sr}_{V}\right)$ \\
\hline 3 & $1-7$ & 3 & 50.3 & 230 \\
\hline 6 & $12-21$ & 4 & 50.6 & 204 \\
\hline $3+6$ & $1-21$ & 5 & 50.4 & 215 \\
\hline $3-1$ & $1-4$ & 6 & 45.7 & 183 \\
\hline $6-1$ & $19-22$ & 7 & 51.8 & 134 \\
\hline $6-2$ & 12 & 8 & 82.4 & 160 \\
\hline
\end{tabular}

$230 \mathrm{ppm}$. The variation is not excessive and may be accountable by slight changes in the mineral composition of the sediment components delivered to the site of deposition.

The concentrations of the sialic component in all of the samples were estimated from Equation 1 by substituting their $\mathrm{Sr}$ concentrations (Table 2) and the values of $\mathrm{Sr}_{s}$ and $\mathrm{Sr}_{v}$ listed in Table 3. Except for the previously identified subsets, we assumed $\mathrm{Sr}_{s}=50.4$ ppm and $\mathrm{Sr}_{v}=215 \mathrm{ppm}$ for all samples, even though we are presently unable to demonstrate that they satisfy the combined mixing Equation 5 because their ${ }^{87} \mathrm{Sr} /{ }^{86} \mathrm{Sr}$ ratios have not yet been measured. Samples belonging to subsets identified in Figure 1 were evaluated by use of the appropriate values of $\mathrm{Sr}_{s}$ and $\mathrm{Sr}_{v}$ listed in Table 3. The results were averaged for each core and are listed in Table 4 together with average values for the carbonate contents, $\mathrm{Sr}$ concentrations and ${ }^{87} \mathrm{Sr} /{ }^{86} \mathrm{Sr}$ ratios. These data were plotted versus their respective core numbers in Figure 2 in order to facilitate their evaluation.

The concentration of the sialic component, indicated by the foregoing treatment of the data, increases from about $57 \%$ in Core 1 to $67 \%$ in Core 7 . It decreases to $40 \%$ in Core 10 and then rises again to about $64 \%$ in Core 12. Thus we place the upper boundary of the Würm/Riss interglacial at the bottom of Core 7 and its lower boundary at the top of Core 12. These results are compatible with the age assignment in Table 1. The abundance of sialic detritus remains high from Core 12 to Core 18 which represent the Riss glacial period. Stoffers et al. (this volume; Table 1) placed the lower boundary of the Riss sediment at the base of Core 24 . However, we infer low concentrations of sialic detritus in Cores 19 through 22 (subset 6-1) and prefer to place the lower boundary of Riss age sediment at the base of Core 18. Therefore, Mindel/Riss interglacial sediment extends from the top of Core 19 to the base of Core 29 . We have no samples from Cores 23 through 35 and are unable to define the boundary between the Min$\mathrm{del} / \mathrm{R}$ iss and the underlying Mindel sediment. According to Stoffers et al. (this volume; Table 1), the Mindel extends through Cores 30 to 49 . We have data for only four cores from this interval which suggest a high average content of sialic detritus of about $84 \%$. The calcite-rich muds which underlie the Mindel section (Cores 50 to 68 , Unit 9) appear to have somewhat lower concentrations of the sialic component with an average of about $70 \%$.
TABLE 4

Summary of Analytical Results and Estimated Abundancies of the Sialic (Northern) Component for Cores From DSDP Hole 379A

\begin{tabular}{rcrrrr}
\hline & & & \multicolumn{3}{c}{ Non-Carbonate Fraction } \\
Core & $\begin{array}{c}\text { No. of } \\
\text { Samples }\end{array}$ & $\begin{array}{c}\text { Carbonate } \\
(\%)\end{array}$ & $\begin{array}{c}\text { St } \\
\text { (ppm) }\end{array}$ & $\begin{array}{c}87 \text { Sr } \\
86 \mathrm{Sr}\end{array}$ & $\begin{array}{c}\text { Sialic Comp. } \\
(\%)\end{array}$ \\
\hline 1 & 2 & $24.7(2)$ & $113.4(2)$ & $0.7118(2)$ & 56.7 \\
4 & 3 & $22.1(3)$ & $103.7(3)$ & $0.7132(3)$ & 61.9 \\
6 & 6 & $19.7(2)$ & $130.1(5)$ & $0.7121(5)$ & 51.5 \\
7 & 3 & $21.6(3)$ & $100.4(3)$ & $0.7143(2)$ & 66.7 \\
8 & 2 & $18.1(2)$ & $113.5(2)$ & - & 61.6 \\
9 & 4 & $18.3(4)$ & $135.9(4)$ & - & 48.0 \\
10 & 5 & $17.8(5)$ & $148.7(5)$ & $0.7169(1)$ & 40.2 \\
11 & 4 & $19.9(3)$ & $128.3(3)$ & $0.7143(2)$ & 52.6 \\
12 & 3 & $20.7(3)$ & $110.4(3)$ & $0.7209(2)$ & 63.8 \\
13 & 5 & $21.6(5)$ & $119.8(5)$ & $0.7117(5)$ & 57.8 \\
14 & 3 & $21.7(3)$ & $108.4(3)$ & $0.7142(2)$ & 64.7 \\
15 & 3 & $19.9(2)$ & $113.4(2)$ & $0.7145(1)$ & 61.7 \\
16 & 4 & $13.2(4)$ & $80.0(4)$ & $0.7170(3)$ & 83.2 \\
18 & 1 & $20.4(1)$ & $95.2(1)$ & - & 72.7 \\
19 & 4 & $21.1(3)$ & $119.5(3)$ & $0.7102(2)$ & 38.6 \\
20 & 1 & $26.0(1)$ & $100.9(1)$ & $0.7110(1)$ & 40.2 \\
21 & 2 & $25.3(2)$ & $106.4(2)$ & $0.7115(1)$ & 33.4 \\
22 & 1 & $26.3(1)$ & $103.9(1)$ & $0.7103(1)$ & 36.6 \\
36 & 1 & $23.6(1)$ & $87.7(1)$ & - & 77.3 \\
38 & 2 & $14.2(2)$ & $67.6(2)$ & $0.7306(1)$ & 89.5 \\
39 & 1 & $11.7(1)$ & $82.5(1)$ & - & 80.4 \\
43 & 1 & $23.3(1)$ & $68.4(1)$ & - & 89.0 \\
51 & 1 & $32.9(1)$ & $104.9(1)$ & - & 66.8 \\
54 & 1 & $33.3(1)$ & $75.0(1)$ & - & 85.0 \\
58 & 1 & $42.6(1)$ & $99.2(1)$ & - & 70.3 \\
60 & 1 & $37.4(1)$ & - & - & - \\
68 & 1 & $32.8(1)$ & $117.2(1)$ & - & 59.4 \\
\hline
\end{tabular}

Note: The numbers in parentheses indicate the number of samples included in each average. The estimates of the abundance of the sialic component were obtained from Equation 1 using the data in Table 3 and the measured $\mathrm{Sr}$ contents.

We conclude that the interpretation of $\mathrm{Sr}$ concentrations and ${ }^{87} \mathrm{Sr} /{ }^{86} \mathrm{Sr}$ ratios of the detrital non-carbonate fractions, by means of the two-component mixing hypothesis, is valid as a first approximation and provides useful information about the stratigraphic variations of the abundance of the sialic component derived from the northern watershed of the Black Sea. The effect of climatic variations during the Pleistocene epoch can be recognized and is compatible with age assignments based on sedimentological and mineralogical criteria. Additional measurements of ${ }^{87} \mathrm{Sr} /{ }^{86} \mathrm{Sr}$ ratios may permit us to define the mixing equations more precisely and to improve the accuracy of the estimated concentrations of the sialic component.

\section{CARBONATE FRACTIONS}

The carbonate fraction of sediment in Cores 1 through 49 of Hole $379 \mathrm{~A}$ consists primarily of coccolith ooze. Chemically precipitated carbonate minerals predominate only in Unit 9 (Cores 50 to 68). The calcareous nannoplankton of Cores 1 through 12 consists of occasional floods of the indigenous species Emiliania huxleyi (Lohman) and Gephyrocapsa caribbeanica Boudreaux and Hay, together with reworked species of Cretaceous and Eocene to Oligocene age (Percival, this report). The indigenous species disappear in Section 5 of Core 11 and are not found again until Core 25 in which Braarudosphaera bigelowi (Gran and Braarud) makes a brief appearance. 


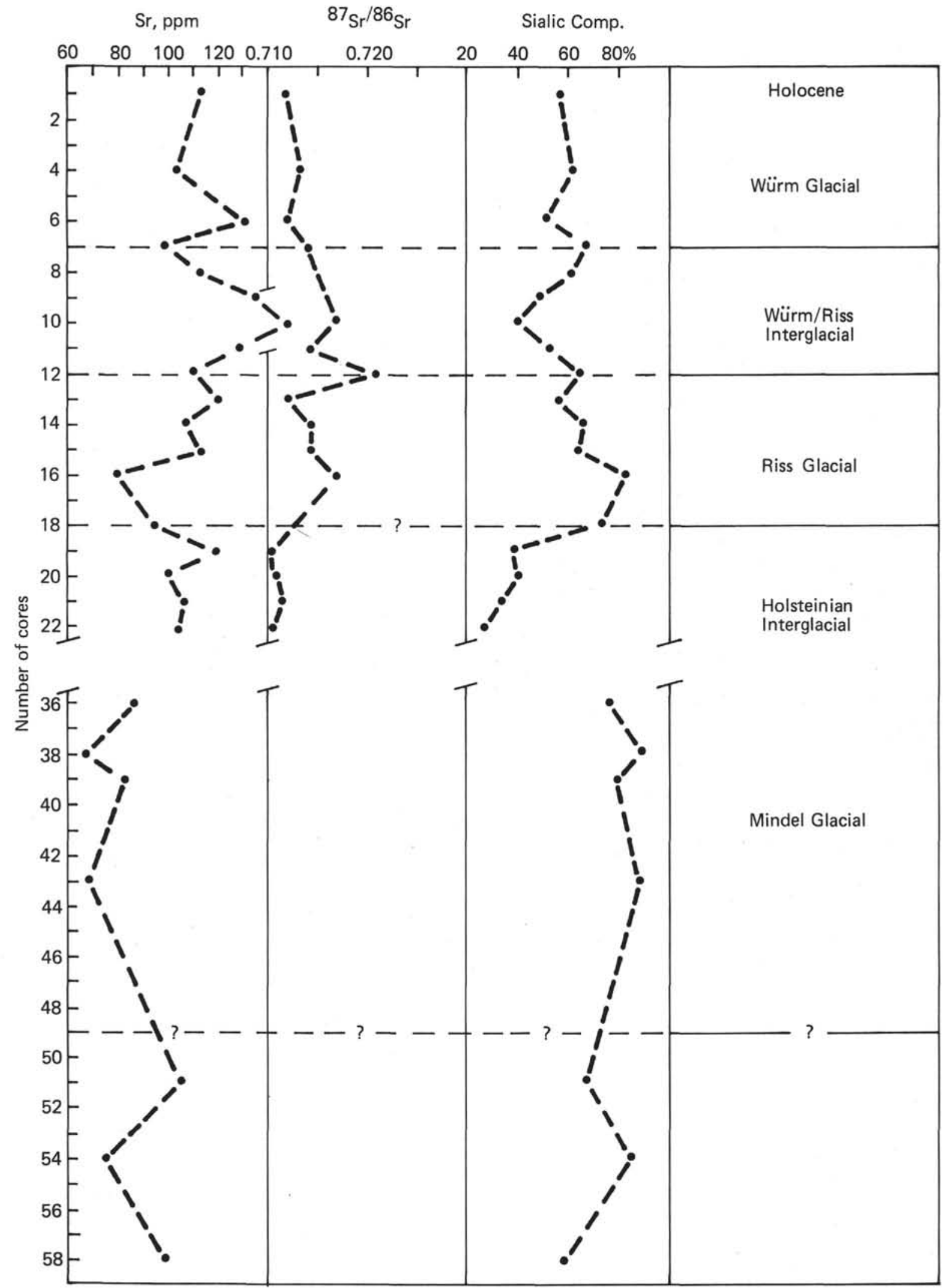

Figure 2. Stratigraphic variation of average $\mathrm{Sr}$ concentrations, ${ }^{87} \mathrm{Sr} /{ }^{86} \mathrm{Sr}$ ratios and estimated abundances of the sialic components in cores of DSDP Hole 379A. The sediment deposited during glacial periods is enriched in sialic detritus from the northern watershed, as expected. The placement of the boundaries of the Würm/Riss interglacial is consistent with that in Table 1. The top of Mindel/Riss interglacial sediment is tentatively placed at the top of Core 19 due to the low content of sialic detritus in Cores 19 to 22 of subset 6-2. 
The isotopic composition of $\mathrm{Sr}$ in the indigenous coccoliths is very probably identical to that of the water in the Black Sea at the time of deposition. The present ${ }^{87} \mathrm{Sr} /{ }^{86} \mathrm{Sr}$ ratio of the Black Sea is $0.7093 \pm 0.0007$ (Cox and Faure, 1974) which is typical of modern ocean water. However, the reworked older coccoliths have significantly lower ${ }^{87} \mathrm{Sr} /{ }^{86} \mathrm{Sr}$ ratios, depending on their age. Measurements by Peterman et al. (1970) indicate that the ${ }^{87} \mathrm{Sr} /{ }^{86} \mathrm{Sr}$ ratio of the oceans increased from 0.70713 (Hauterivian) to 0.70730 (Albian) in Early Cretaceous time and rose to 0.70746 during the Late Cretaceous. The corresponding values of this ratio in the oceans during the middle Eocene and Oligocene epoch were 0.70780 and 0.70804 , respectively. Since the carbonate fractions of sediment above Unit 9 at Hole $379 \mathrm{~A}$ are mixtures of indigenous and reworked older coccoliths, their ${ }^{87} \mathrm{Sr} /{ }^{86} \mathrm{Sr}$ ratios should presumably vary between 0.707 and 0.709 .

The ${ }^{87} \mathrm{Sr} /{ }^{86} \mathrm{Sr}$ ratios of carbonate fractions from 15 samples representing Cores 1 through 22 (Table 5) actually range from 0.7070 to 0.7084 . Four samples from Unit 3, deposited during the Würm glaciation, have an average ${ }^{87} \mathrm{Sr} /{ }^{86} \mathrm{Sr}$ ratio of $0.7075 \pm 0.00014$ (1 $\sigma$ ). The highest value occurs in Core 4 (Sample 4-4, 50 $\left.\mathrm{cm},{ }^{87} \mathrm{Sr} /{ }^{86} \mathrm{Sr}=0.7078\right)$ which contains an abundance of Emiliania huxleyi (Percival, this volume) as well as abundant older species. This core also contains radiolarians indicative of "marine" conditions (Schrader, personal communication). The slight increase of the ${ }^{87} \mathrm{Sr} /{ }^{86} \mathrm{Sr}$ ratio in Core 4 is therefore compatible with the paleontological data and signals a temporary increase in salinity of the Black Sea.

The ${ }^{87} \mathrm{Sr} /{ }^{86} \mathrm{Sr}$ ratios of carbonate fractions in Cores 8 to 11 (Unit 4, Würm/Riss interglacial) are significantly higher than those of Unit 3 and average 0.7080 $\pm 0.00014(1 \bar{\sigma})$. These cores all contain floods of indigenous coccoliths mixed with reworked older species which are generally "rare" to "common." The high ${ }^{87} \mathrm{Sr} /{ }^{86} \mathrm{Sr}$ ratio of the carbonate phase during the Würm/Riss interglacial period is consistent with the abundance of Emiliania huxleyi and suggests higher salinity in the Black Sea at this time. These results confirm the hypothesis of Cox and Faure (1974) and strengthen their suggestion that the ${ }^{87} \mathrm{Sr} /{ }^{86} \mathrm{Sr}$ ratio of the carbonate fraction is controlled by the mixture of indigenous and reworked older coccoliths.

The carbonate fractions of Unit 6 (including Cores 12 through 18), deposited during the Riss glaciation, generally have high ${ }^{87} \mathrm{Sr} /{ }^{86} \mathrm{Sr}$ ratios averaging 0.7079 $\pm 0.00022(1 \bar{\sigma})$. The only low value $(0.7070)$ was observed in Sample 12-1, $53 \mathrm{~cm}$. These cores contain no indigenous coccoliths and only occasional mollusk shell fragment in Cores 16 and 17 (Percival, this volume) which indicates fresh-water conditions in the Black Sea during the Riss glaciation. The higher ${ }^{87} \mathrm{Sr} /{ }^{86} \mathrm{Sr}$ ratios of the carbonate fractions in this interval may be due to dominance of reworked coccoliths of Eocene to Oligocene age which have higher ${ }^{87} \mathrm{Sr} /{ }^{86} \mathrm{Sr}$ ratios than species of Cretaceous age.

One sample from Core $22(22-6,11 \mathrm{~cm})$ has an ${ }^{87} \mathrm{Sr} /{ }^{86} \mathrm{Sr}$ ratio of 0.7084 which is similar to that of Core 18. This result taken by itself does not resolve the question whether the top of the Mindel/Riss-age
TABLE 5

${ }^{87} \mathrm{Sr} /{ }^{86} \mathrm{Sr}$ Ratios of Carbonate Fractions, DSDP Hole 379A, Black Sea

\begin{tabular}{lcl}
\hline $\begin{array}{c}\text { Sample } \\
\text { (Interval in cm) }\end{array}$ & ${ }^{87} \mathrm{Sr} /{ }^{86} \mathrm{Sr}$ & \multicolumn{1}{c}{ Age } \\
\hline $1-1,70$ & 0.7073 & Wurm Glacial \\
$4-4,50$ & 0.7078 & Wurm Glacial \\
$6-5,32$ & 0.7072 & Wurm Glacial \\
$7-4,16$ & 0.7076 & Wurm Glacial \\
Average for Würm Glacial: $0.7075 \pm 0.00014(1 \bar{\sigma})$ \\
$8-5,26$ & 0.7078 & Wurm/Riss Interglacial \\
$9-5,136$ & 0.7079 & Wurm/Riss Interglacial \\
$10-4,70$ & 0.7084 & Wurm/Riss Interglacial \\
$11-4,50$ & 0.7079 & Wurm/Riss Interglacial \\
Average for Würm/Riss Interglacial: 0.7080 $0.00014(1 \bar{\sigma})$ \\
$12-1,53$ & 0.7070 & Riss Glacial \\
$12-2,24$ & 0.7082 & Riss Glacial \\
$13-4,24$ & 0.7084 & Riss Glacial \\
$15-4,13$ & 0.7077 & Riss Glacial \\
$16-4,56$ & 0.7083 & Riss Glacial \\
$18-2,48$ & 0.7080 & Riss Glacial \\
Average for Riss Glacial: $0.7079 \pm 0.00022(1 \bar{\sigma})$ \\
$22-6,11$ & 0.7084 & Mindel/Riss Interglacial? \\
\hline
\end{tabular}

sediment occurs at the top of Core 25 (Stoffers et al., this volume) or at the top of Core 19 as suggested in Figure 2.

The $\mathrm{Sr}$ concentrations of calcite in Cores 36 to 45 of Unit 8 range from 628 to $859 \mathrm{ppm}$ and average $719 \pm 37$ ppm $(1 \sigma)$. Those of Cores 51 to 68 (Unit 9) are very similar and have a mean $\mathrm{Sr}$ content of $658 \pm 20 \mathrm{ppm}(1$ $\bar{\sigma})$. These results are quite normal for calcite which generally contains less $\mathrm{Sr}$ than aragonite but more than dolomite.

\section{CONCLUSIONS}

The results of this study can be summarized as follows:

1) The $\mathrm{Sr}$ concentrations and ${ }^{87} \mathrm{Sr} /{ }^{86} \mathrm{Sr}$ ratios of detrital, noncarbonate sediment deposited at DSDP Hole 379A are controlled to a first approximation by the relative abundances of a sialic component derived from the watershed north of the Black Sea and a more mafic component that originated in Turkey and Bulgaria.

2) The estimated values of the abundance of the sialic component, derived from a two-component mixing model, vary systematically as a function of depth and confirm that the input of this component increased during periods of glaciation and decreased during interglacials in northern Europe.

3) Short-term variations in the $\mathrm{Sr}$ contents and ${ }^{87} \mathrm{Sr} /{ }^{86} \mathrm{Sr}$ ratios of the two sediment components delivered to this site can be recognized (provided samples are available) and can be accommodated by the derivation of discrete mixing equations relevant to specific stratigraphic intervals.

4) $\mathrm{The}{ }^{87} \mathrm{Sr} /{ }^{86} \mathrm{Sr}$ ratios of carbonate fractions are controlled by the relative abundances of indigenous and older reworked coccoliths, provided that chemically precipitated carbonate minerals are not dominant.

5) Saline conditions in the Black Sea during the Würm/Riss interglacial are reflected by high ${ }^{87} \mathrm{Sr} /{ }^{86} \mathrm{Sr}$ 
ratios $(0.7080 \pm 0.00014)$, whereas fresh-water conditions during the Würm glacial period are indicated by a lower average value of this ratio $(0.7075$ \pm 0.00014 .)

6) $\mathrm{The}{ }^{87} \mathrm{Sr} /{ }^{86} \mathrm{Sr}$ ratios of carbonate phases of Riss age sediment are high $(0.7079 \pm 0.00022)$ even though indigenous coccoliths are absent, perhaps because of the dominance of reworked Tertiary coccoliths which have higher ${ }^{87} \mathrm{Sr} /{ }^{86} \mathrm{Sr}$ ratios than those of Cretaceous age.

\section{ACKNOWLEDGMENTS}

We thank David A. Ross of the Woods Hole Oceanographic Institution for the opportunity to participate in the study of core samples recovered during Leg 42B of the Deep Sea Drilling Project. The samples were collected by E.T.Degens and Peter Stoffers during the cruise and were transmitted to us by W.G. Deuser. This study was supported by the Oceanography Section of the National Science Foundation through Grant DES75-03203.

\section{REFERENCES}

Boger, P.D. and Faure, G., 1974. Strontium-isotope stratigraphy of a Red Sea core: Geology, v. 2, p. 181-183. 1976. Systematic variations of sialic and volcanic detritus in piston cores from the Red Sea: Geochim. Cosmochim. Acta, v. 40, p. 731-742:

Brinkman, R., 1974. Geologic relations between Black Sea and Anatolia. In Degens, E.T., and Ross, D.A. (Eds.), The Black Sea-geology, chemistry and biology: Am. Assoc. Petrol. Geol. Mem. 20, p. 63-76.

Bukry, D., 1974. Coccoliths as paleosalinity indicators. In Degens, E.T. and Ross, D.A. (Eds.), Black Sea-geology, chemistry, biology: Am. Assoc. Petrol. Geol. Mem. 20, p. 353-363.

Cooper, J.A., Dasch, E.J., and Kaye, M., 1974. Isotopic and elemental geochemistry of Black Sea sediments. In Degens, E.T. and Ross, D.A. (Eds.), Black Sea-geology, chemistry and biology: Am. Assoc. Petrol. Geol. Mem. 20, p. 554-565.

Cox, J.M. and Faure, G., 1974. Isotope composition of strontium in carbonate phase of two cores from Black Sea.
In Degens, E.T. and Ross, D.A. (Eds.), Black Sea-geology, chemistry and biology: Am. Assoc. Petrol. Geol. Mem. 20, p. 566-569.

Faure, G. and Powell, J.L., 1972. Strontium isotope geology: New York (Springer-Verlag).

Flanagan, F.J., 1973. 1972 values for international geochemical reference samples: Geochim. Cosmochim. Acta, v. 37, p. 1189-1200.

Kamen-Kaye, M., 1971. A review of depositional history and geological structure in Turkey. In Campbell, A.S. (Ed.), Geology and history of Turkey: Libya (Petrol. Explor. Soc.), p. 111-138.

Müller, G. and Stoffers, P., 1974. Mineralogy and petrology of Black Sea basin sediments. In Degens, E.T. and Ross, D.A. (Eds.), The Black Sea-geology, chemistry and biology: Am. Assoc. Petrol. Geol. Mem. 20, p. 200-248.

Peterman, Z.E. and Hedge, C.E., 1971. Related strontium isotopic and chemical variations in oceanic basalts: Geol. Soc. Am. Bull., v. 82, p. 493-500.

Peterman, Z.E., Coleman, R.G., and Hildreth, R.A., 1971. $\mathrm{Sr}^{87} / \mathrm{Sr}^{86}$ in mafic rocks of the Troodos Massif, Cyprus: U.S. Geol. Surv. Prof. Paper, 750-D, p. 157-161.

Peterman, Z.E., Hedge, C.E., and Tourtelot, H.A., 1970. Isotopic composition of strontium in sea water throughout Phanerozoic time: Geochim. Cosmochim. Acta, v. 34, p. $105-120$.

Reynolds, R.C., 1963. Matrix correction in trace element analysis by X-ray fluorescence: Estimation of the mass absorption coefficient by Compton scattering: Am. Mineralogist, v. 48, p. 1133-1143.

Ross, D.A. and Degens, E.T., 1974. Recent sediments in the Black Sea. In Degens, E..T. and Ross, D.A. (Eds.), Black Sea-geology, chemistry and biology: Am. Assoc. Petrol. Geol. Mem. 20, p. 183-199.

Shaffer, N.R. and Faure, G., 1976. Regional variation of ${ }^{87} \mathrm{Sr} /{ }^{86} \mathrm{Sr}$ ratios and mineral compositions of sediment from the Ross Sea, Antarctica: Geol. Soc. Am. Bull.; v. 87 , p. $1491-1500$.

Vuchev, V.T., 1974. Black Sea studies in Bulgaria-A brief survey. In Degens, E.T. and Ross, D. A. (Eds.), The Black Sea-geology, chemistry and biology: Am. Assoc. Petrol. Geol. Mem. 20, p. 90-96. 